\title{
Hydrological and planting design of an experimental raingarden at the Royal Botanic Garden Edinburgh
}

\author{
David A. Kelly', Kirsty Wilson², Aravindan Kalaichelvam³ \& David Knott ${ }^{4}$
}

\begin{abstract}
A new experimental raingarden has been created the Royal Botanic Garden Edinburgh (RBGE) to help cope with the impacts of more frequent and intense rainfall events. Raingardens offer a sustainable, nature-based solution to flood mitigation by mimicking natural rainwater retention and infiltration characteristics within a constructed bioretention system. By incorporating specially selected plants that can withstand both very wet and very dry conditions, raingardens also provide enhanced biodiversity capacity.

This paper reports on the hydrological design of the raingarden, which is aimed at reducing the occurrence of waterlogging and localised flooding within RBGE, before discussing the selection and cultivation of the planting. It is hoped that the mix of plants chosen will encourage a great diversity of wildlife, providing nectar sources for insects and bees in summer, and homes for invertebrates and food for seed-eating birds in winter. With the raingarden having been in place for over a year at the time of writing, reflections on its maintenance and upkeep during that time and performance assessment for significant storm events will also be discussed.
\end{abstract}

\section{Introduction}

As a world-renowned centre for plant science and horticulture, the Royal Botanic Garden Edinburgh (RBGE) plays a vital role in connecting people with the natural environment (Foulkes, 2017). Hundreds of thousands of visitors from all over the world come each year to visit its rich collection of native and non-native plants which have been curated over its 350-year history (RBGE, 2019). However, like many organisations around the world, in recent years RBGE has begun to experience the impacts of changing weather patterns as a consequence of climate change.

A particular challenge has been the change in rainfall patterns, with longer periods of dry weather followed by more frequent heavy downpours of rain proving particularly problematic in terms of maintaining plant health and avoiding localised flood issues (Martin, 2014). Heavy rainfall events have brought problems of waterlogging and localised flooding to some

${ }^{1}$ David A. Kelly is Assistant Professor at the Institute of Sustainable Building Design at Heriot-Watt University.

Address: Edwin Chadwick Building, Heriot-Watt University, Edinburgh, EH14 4AS, UK.

Email: D.A.Kelly@hw.ac.uk

${ }^{2}$ Kirsty Wilson is Herbaceous Supervisor at the Royal Botanic Garden Edinburgh.

Address: 20A Inverleith Row, Edinburgh, EH3 5LR, UK.

${ }^{3}$ Aravindan Kalaichelvam is a PhD student at the Institute of Sustainable Building Design at Heriot-Watt University and

Senior Engineer in the Infrastructure division at Atkins.

Address: Edwin Chadwick Building, Heriot-Watt University, Edinburgh, EH14 4AS, UK.

${ }^{4}$ David Knott is Curator of Living Collections at the Royal Botanic Garden Edinburgh.

Address: 20A Inverleith Row, Edinburgh, EH3 5LR, UK. 
parts of the Garden, causing damage to plant beds, lawns and footpaths, and impacting visitor access due to the closure of affected areas.

With extreme weather events expected to become more frequent and intense over the coming decades (Murphy et al., 2018), staff at RBGE are working to find ways to increase the resilience of the Garden to extreme events, and to reduce its vulnerability to climate change. In collaboration with engineers from Heriot-Watt University, an experimental raingarden was designed to provide a sustainable solution to managing rainwater runoff at an area of the Garden known as the Birch Lawn, which has historically suffered from recurring flooding and waterlogging due to its low-lying position.

Different from conventional piped drainage systems, raingardens offer a sustainable approach to flood mitigation by mimicking natural rainwater retention and infiltration characteristics, whilst also promoting improved biodiversity. Designed as a shallow basin with absorbent yet free-draining soil, and planted with vegetation that can withstand occasional drought and flooding, raingardens attenuate rainwater runoff by encouraging it to drain naturally into the ground or be taken up by the plants and lost to the air by evapotranspiration (Bray et al., 2012). Shaping the raingarden as a shallow basin provides an important ponding area at the surface for the temporary storage of rainwater before infiltration, evaporation and plant uptake occurs (Woods-Ballard et al., 2015).

The types of plant used (i.e. herbaceous or woody, or deciduous or evergreen) significantly affect evapotranspiration rates, as do environmental factors such as solar radiation, humidity, air temperature and wind (Novák, 2012). The evaporation of water accumulated on the plant surface, defined as the rainwater intercepted by the plant, is dependent upon the plant's physical attributes, such as the reflectivity of its surfaces and the leaf area and shape. As the water transpired through leaves comes from the roots, plants with deep-reaching roots can transpire water more constantly. Furthermore, deciduous plants which die back each year will contribute almost nothing to evapotranspiration during the winter months; however, whilst they may have lost their foliage above ground, these types of plant will still take up water in winter months via their root system. Consideration of the types of plant used in a raingarden should take account of such factors, due not only to their impacts on evapotranspiration throughout the year, but also to the aesthetics of the raingarden from season to season. Whilst the rates of evapotranspiration may reduce in winter as plants die back and the air temperature drops, the effectiveness and functionality of the raingarden is predominantly based on the retention and attenuation effects of the incorporated soil basin.

Overall, the bioretention characteristics of the raingarden are dependent on several factors, such as: (i) the surface area of the raingarden; (ii) the depth of retention; (iii) the infiltration capacity of the soil; and (iv) the density and choice of planting used (Zhang \& Guo, 2013).

Together with providing rainwater control, the raingarden will also be used as a living laboratory, allowing us to learn more about the trees, shrubs and wildflowers that are best able to help naturally reduce waterlogging and cope with occasional temporary flooding, as well as plants that can 
withstand other extreme weather events such as drought.

The raingarden was completed in spring 2019 and, since then, has successfully intercepted and absorbed excess rainfall runoff during heavy downpours, avoiding floods on nearby paths and capturing rainfall for the benefit of the plants that grow there. In providing a simple, attractive and wildlifefriendly way of reducing flood risk, it is hoped that the raingarden will also raise awareness around nature-based solutions for flood mitigation and provide inspiration for visitors and other institutions who may need to solve similar problems.

This paper gives a brief overview of the rainfall events observed at RBGE as well as their impacts, before then detailing the hydrological design of the raingarden and providing an insight into the selection and cultivation of the native and non-native plants being trialled for their ability to withstand both very wet and very dry conditions. As the raingarden was completed over a year ago, experiences of its maintenance will also be discussed.

\section{Extreme rainfall impacts at RBGE}

Observations of recorded rainfall events at RBGE reflect an increased frequency and severity of intense events, with an overall upward trend of annual rainfall. This can be seen in Fig. 1, which presents the total annual rainfall recorded by the RBGE weather station (an official Met Office weather station) from 1976 until 2019. Whilst the natural variability of annual rainfall can be clearly seen, ranging from a low of $483 \mathrm{~mm}$ in 1989 to a high of $960 \mathrm{~mm}$ in 2012, there is a trend of increasing annual rainfall overall.

Looking at extreme rainfall events more closely, 2012 was the wettest year on record, with total rainfall of $960 \mathrm{~mm}$,

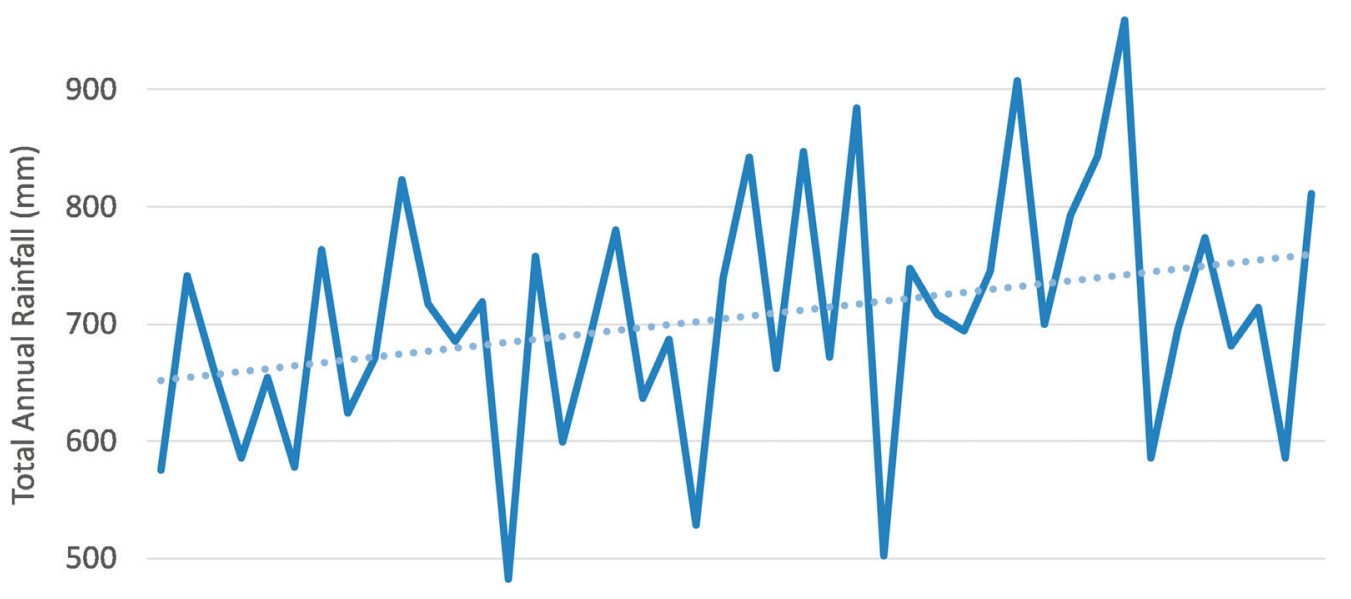

400

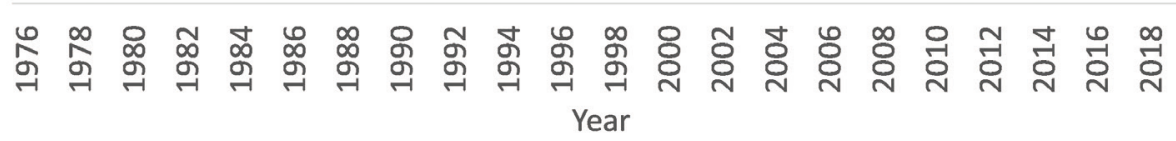

Fig. 1 Total annual rainfall recorded at RBGE (1976-2019) illustrating both the annual variability and the increasing trend. 
1.36 times more than the long-term annual average rainfall $(706 \mathrm{~mm}$, calculated as the average annual rainfall from 1976 to 2019). The wettest month at RBGE was August 2008, which saw $202 \mathrm{~mm}$ of rain (3.16 times more than the average for August - $64 \mathrm{~mm}$ ), followed by July 2012 with $182 \mathrm{~mm}$ of rain (2.73 times more than the average for July $-67 \mathrm{~mm}$ ) and June 2017 with $181 \mathrm{~mm}$ of rain (2.89 times more than the average for June $-63 \mathrm{~mm}$ ). In fact, the summer seasons (from June to August) of those years have been the wettest on record at RBGE, with summer 2012 the wettest (410 $\mathrm{mm}$ of rain), followed by summer 2008 ( $367 \mathrm{~mm})$ and summer 2017 (344 mm). The wettest winter season (from December to February) was 2015/2016 with $360 \mathrm{~mm}$ of rain falling during those three months. Winter 2015/2016 was also the wettest recorded for Scotland and the second-wettest for the UK, beaten only by winter 2013/2014 (Met Office, 2019a). The wettest day recorded at RBGE was 26 July 1985 with $82 \mathrm{~mm}$ of rain over a 24-hour period.
The impact of heavy rainfall events has caused a number of problems across the Garden, including waterlogging and localised flooding. These problems have caused damage to plant beds, lawns and footpaths, and has impacted staff and visitor access due to the closure of affected areas. Figs 2-4 show instances when heavy rain has caused waterlogging of lawns and the submersion of tree and shrub roots - with potential consequences for plant health. Waterlogging of lawns has also affected garden maintenance, making grass cutting difficult and causing soil compaction.

The impact of more extreme rainfall events can be seen in Figs 5 and 6 ; extensive localised flooding occurred in July 2012 (the second-wettest month on record), submerging and blocking a main footpath. After such events, remedial work has been necessary to repair the footpaths and plant beds where soil and surface materials have been washed away.

In contrast, RBGE has also experienced periods drier than average. The driest year from 1976 onwards was 1989, when only 483

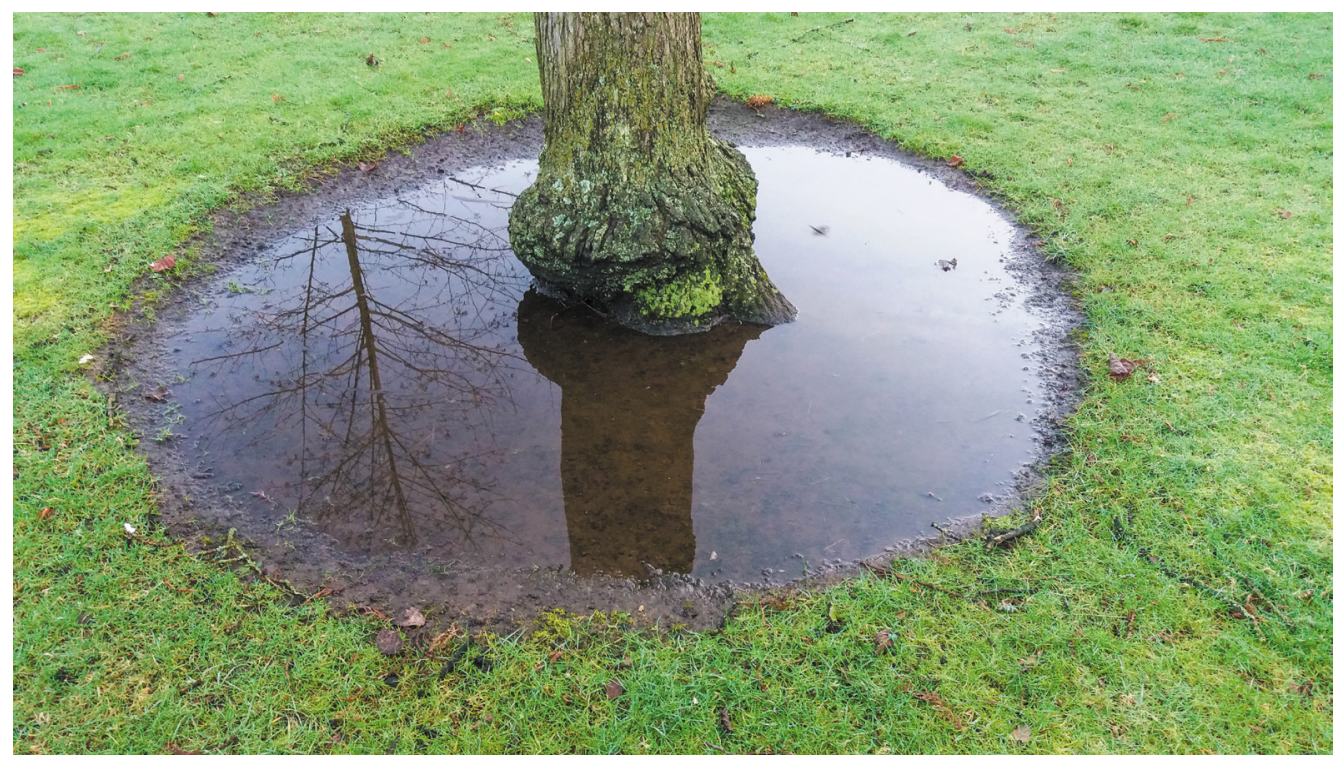

Fig. 2 Tree roots submerged following heavy rain in February 2017. Photo: David Knott, RBGE. 


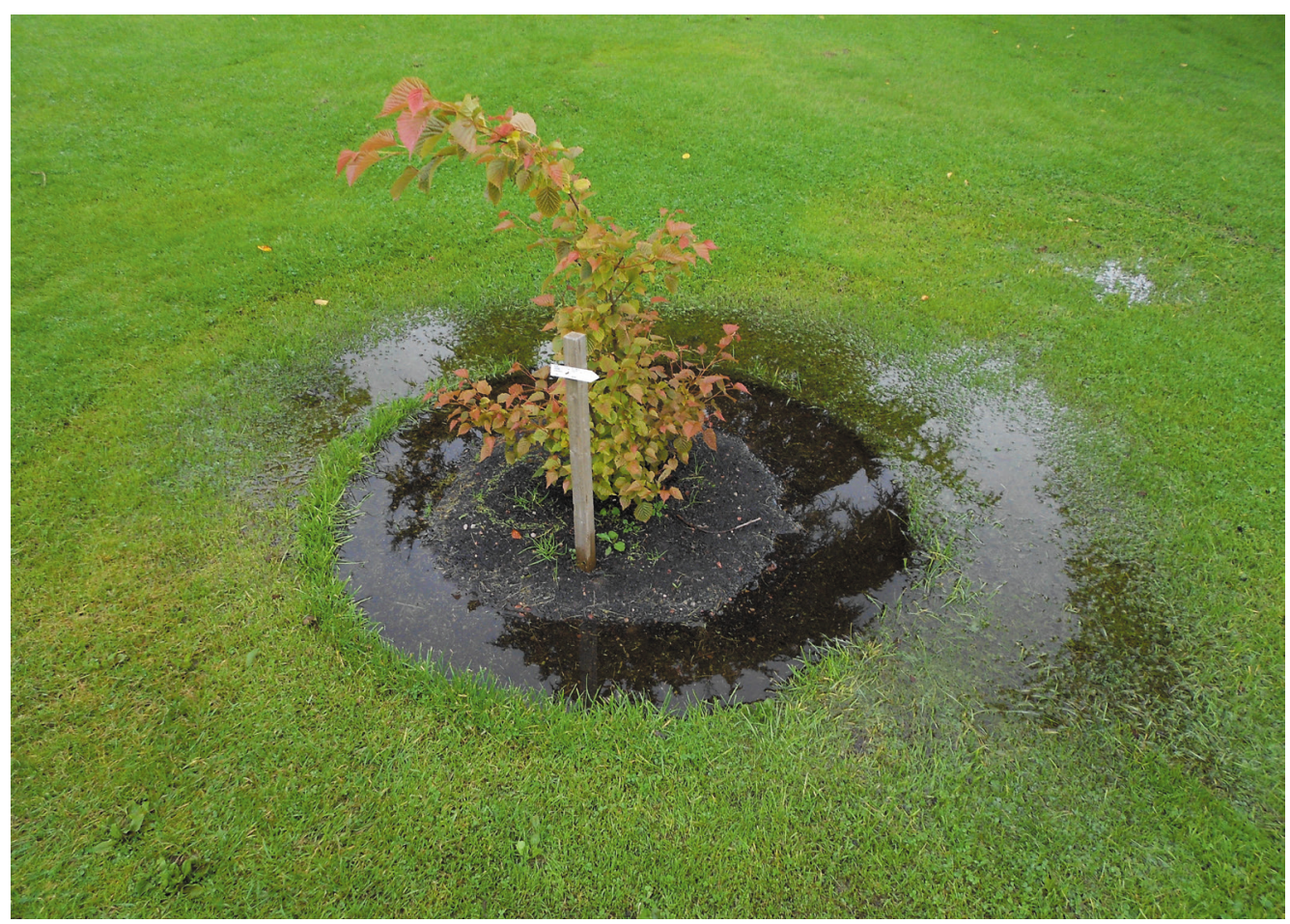

Fig. 3 Shrub roots submerged following heavy rain in February 2017. Photo: David Knott, RBGE.

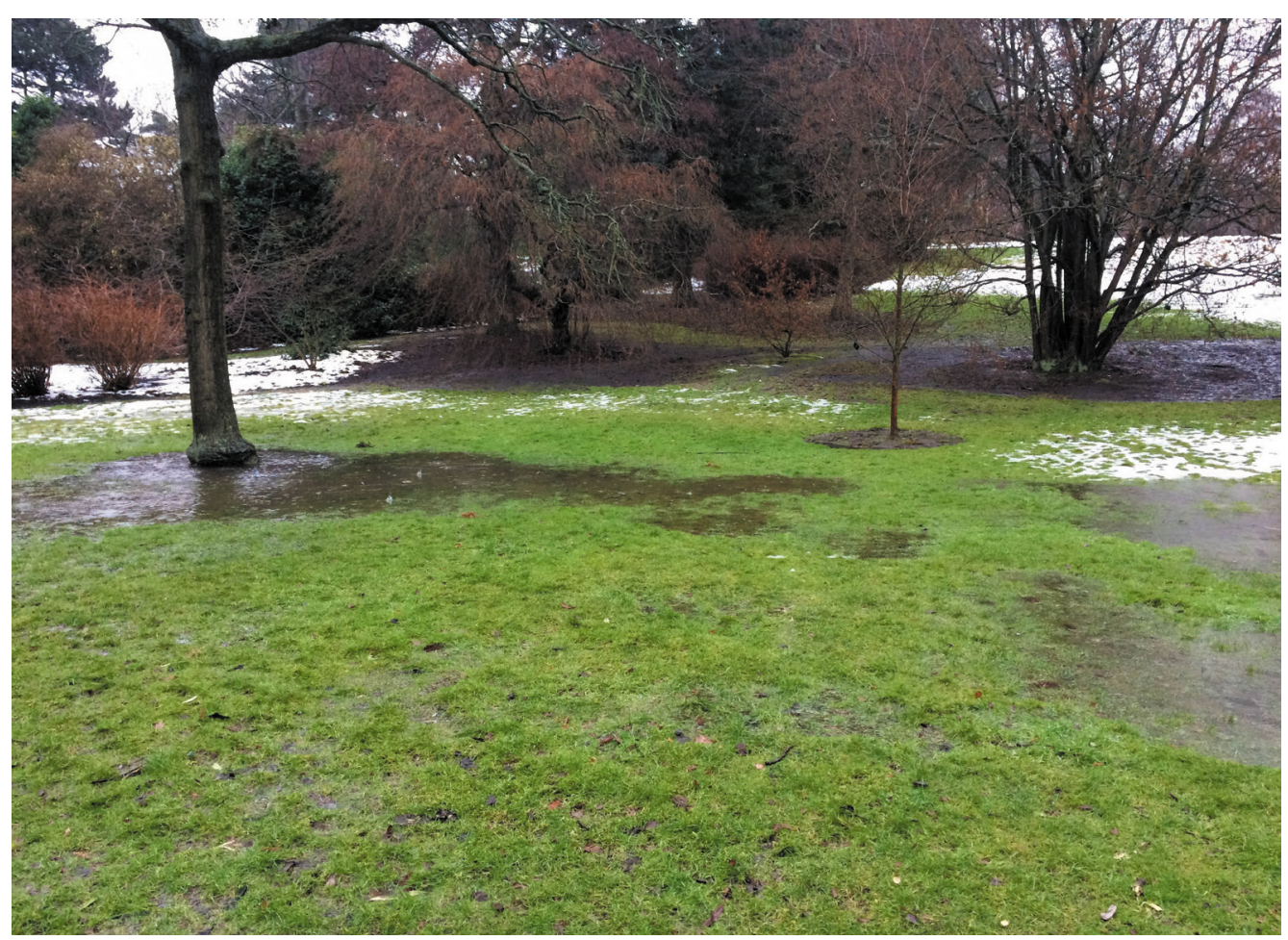

Fig. 4 Waterlogging and root submersion following heavy rain and snow in May 2018. Photo: Leonie Alexander, RBGE. 
6 David A. Kelly, Kirsty Wilson, Aravindan Kalaichelvam \& David Knott

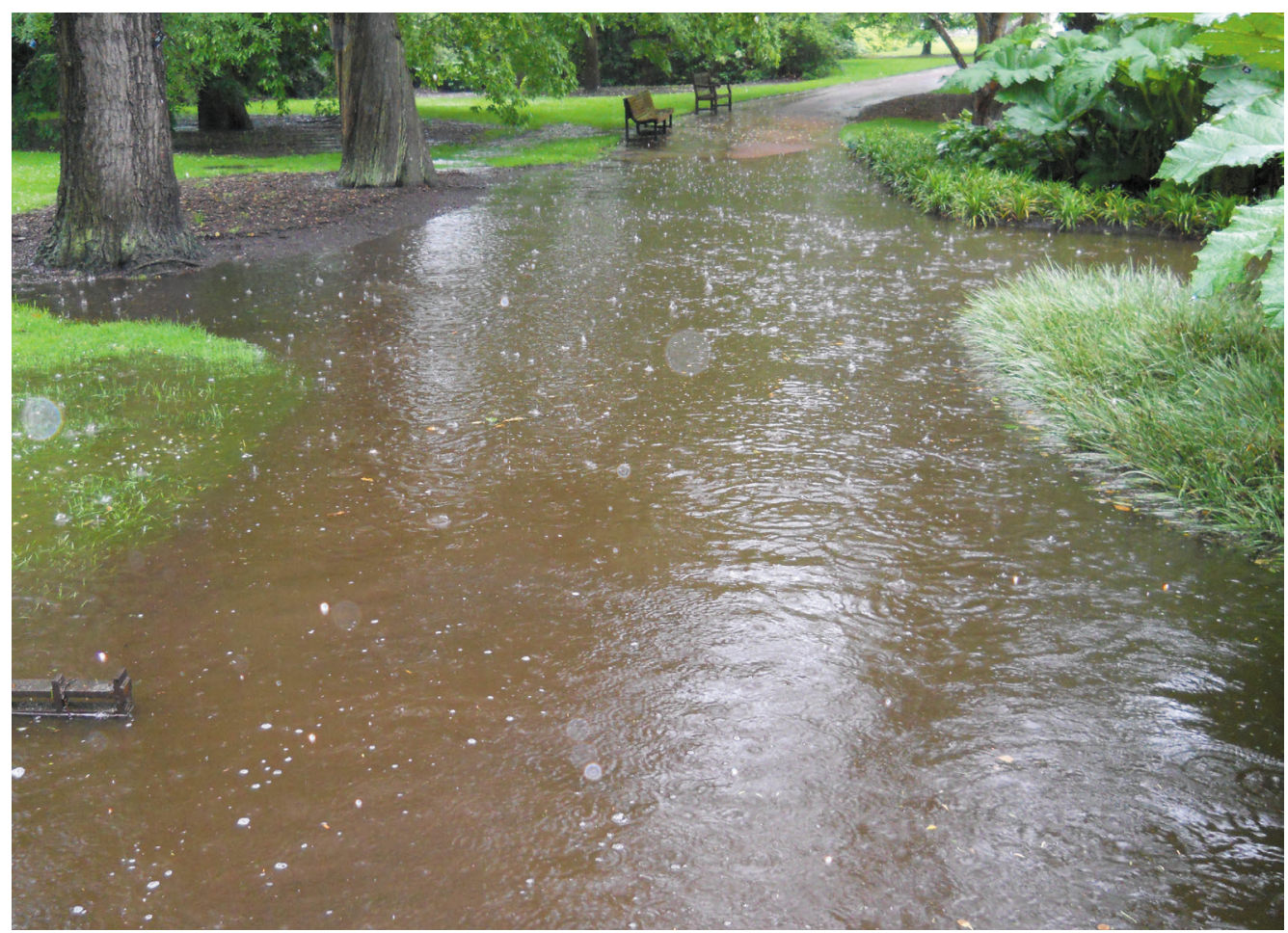

Fig. 5 A section of a main footpath flooded following heavy rain in July 2017. Photo: John Mitchell, RBGE.

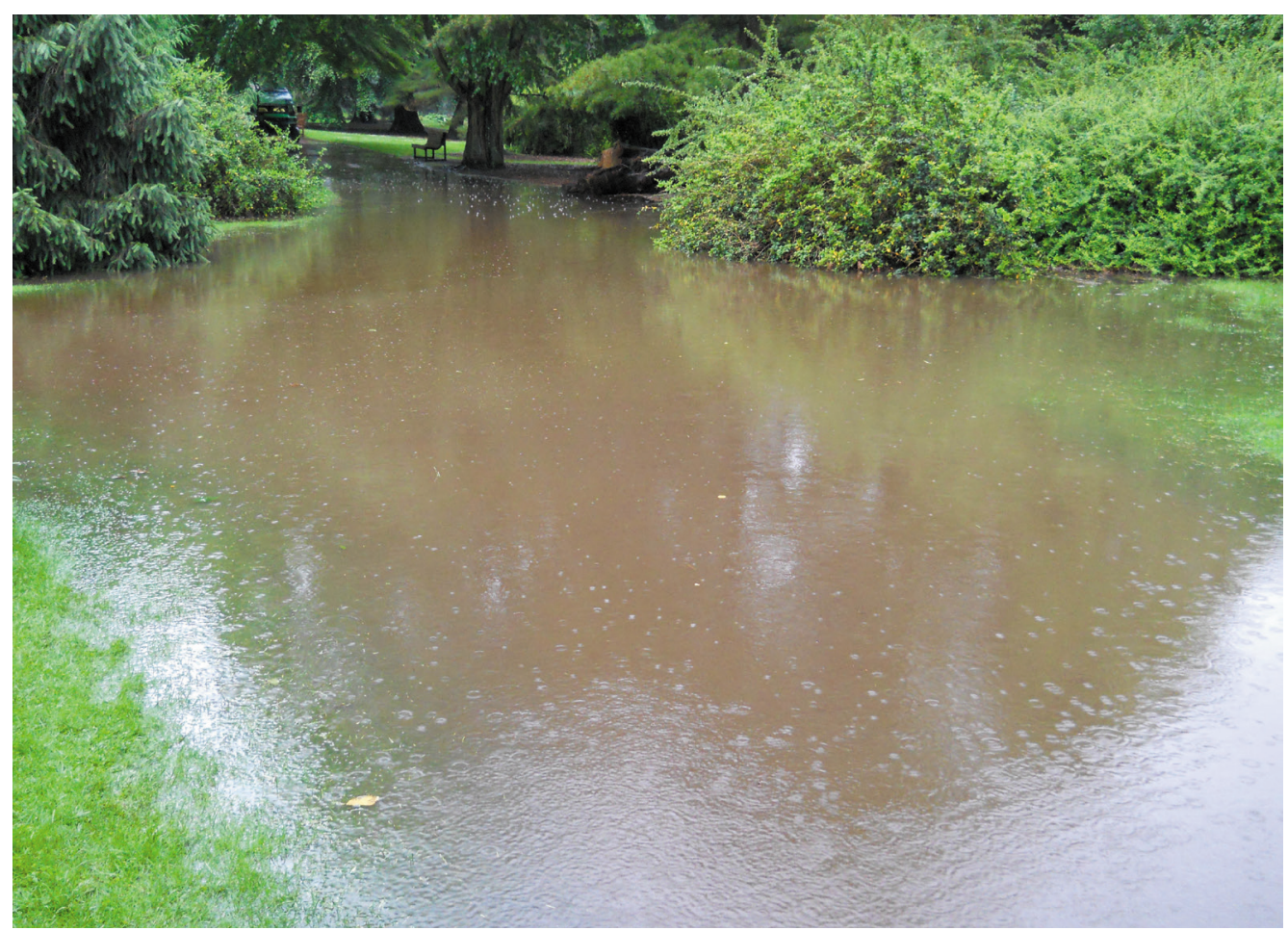

Fig. 6 Further flooding of a main footpath following heavy rain in July 2017. Photo: John Mitchell, RBGE. 
$\mathrm{mm}$ of rain fell (just 68 per cent of the annual average). The driest month was February 1993 when just $3.7 \mathrm{~mm}$ of rain fell. As a result, mulches are now being used to help conserve soil moisture during dry periods.

\section{The hydrological design of the raingarden}

With the primary aim of minimising waterlogging and localised flooding, the first step of the raingarden design was to assess the hydrological requirements. The raingarden was to be located at the Birch Lawn which had historically suffered from waterlogged grass, submerged tree roots and flooded paths. Initial site conditions were assessed by measuring the infiltration rates of the existing local soil. A digital terrain model was then used to assess the surface water flow characteristics at the site and the corresponding dimensions and infiltration requirements of the raingarden. An amended soil was then developed for the raingarden in order to enhance the rate of infiltration and rainwater absorption capabilities.

\section{Soil infiltration tests}

The infiltration rate of the soil at the Birch Lawn was measured using a Mini Disk Infiltrometer (METER Group Inc.). The Infiltrometer is designed to accurately measure the unsaturated hydraulic conductivity of any soil (i.e. the rate at which water can move through the soil).

Infiltration rates varied across the site; however, all were found to be below $20 \mathrm{~mm} / \mathrm{h}$ due to the apparent high clay content of the existing soil. Finer clay soils tend to have very low rates of water transmission and so display low infiltration rates (Natural Resources Conservation Service, 1986). Infiltration rates were also found to be lower for bare, compacted soil, such as those around trees and shrubs. Kelly et al. (2019) provides a detailed description of the infiltration tests and their results.

\section{Digital Terrain Model}

The topography of RBGE was assessed using the Digital Terrain Model (DTM) in QGIS, which is an open-source Geographic Information System. The DTM data used has a grid cell resolution of $2 \mathrm{~m}$ and was sourced from the Environment Agency UK. Fig. 7 shows the site elevations, with the red areas being the highest points within the Garden and the blue areas the lowest points. The Birch Lawn watershed boundary, which is delineated by the blue polygon, can be seen to sit at a natural low point within the Garden.

Fig. 8 shows the rainwater runoff routing at the Birch Lawn. Assessment showed that the rainwater drainage routes slope at a steep fall of 1 in 10 and culminate at the footpath adjacent to the Birch Lawn. The red contour lines indicate a change in elevation of almost $5 \mathrm{~m}$ from the highest point $(23.9 \mathrm{~m})$ to the lowest point $(19 \mathrm{~m})$ over a length of $50 \mathrm{~m}$.

\section{The raingarden dimensions}

Design rainfall data for the RBGE site was obtained from the Flood Estimation Handbook 2013 rainfall model (Centre for Ecology and Hydrology, 2013). This model is widely used for storm drainage design in the UK and is based on the statistical assessment of historic observed rainfall records, providing an estimate of total rainfall depth corresponding to a particular event duration and return period.

The raingarden was designed to intercept rainfall for storm events up to a 30-year return period. To account for future climate change, a 20 per cent uplift was applied, giving a target design rainfall intensity of $32.8 \mathrm{~mm} / \mathrm{h}$. Assuming an existing 


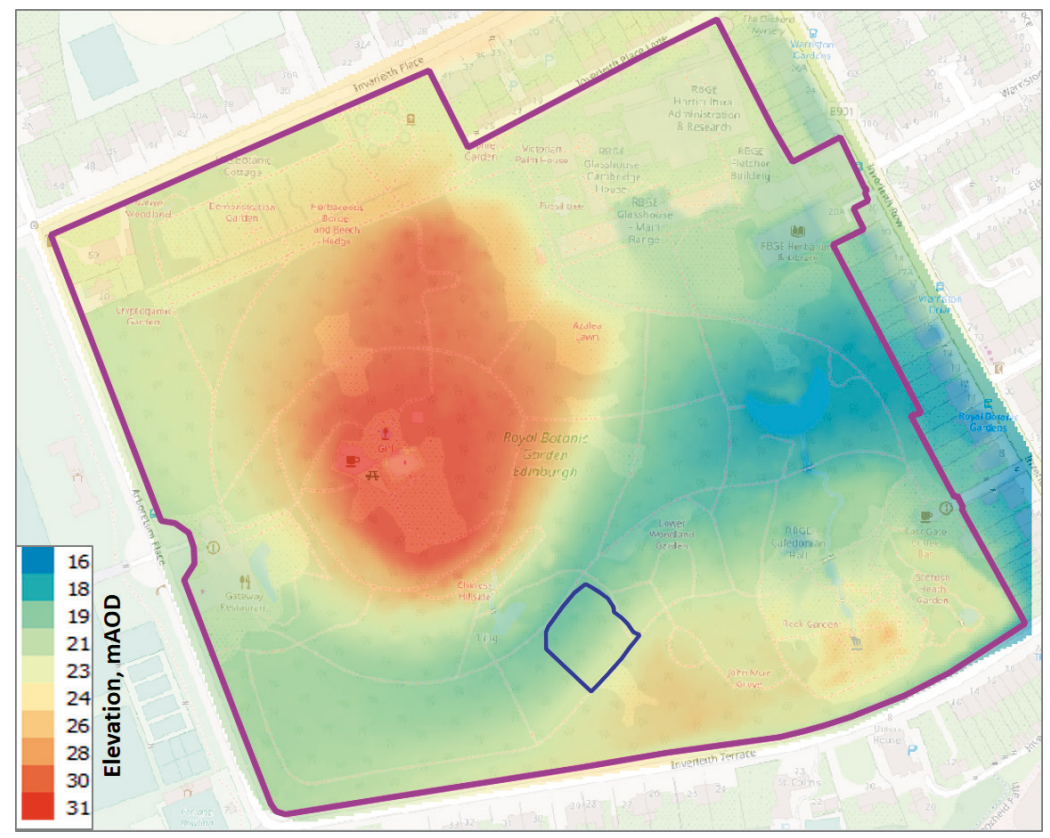

Fig. 7 Site elevations of RBGE depicted by the Digital Terrain Model (DTM), QGIS (red areas indicate the highest points and blue areas the lowest points).

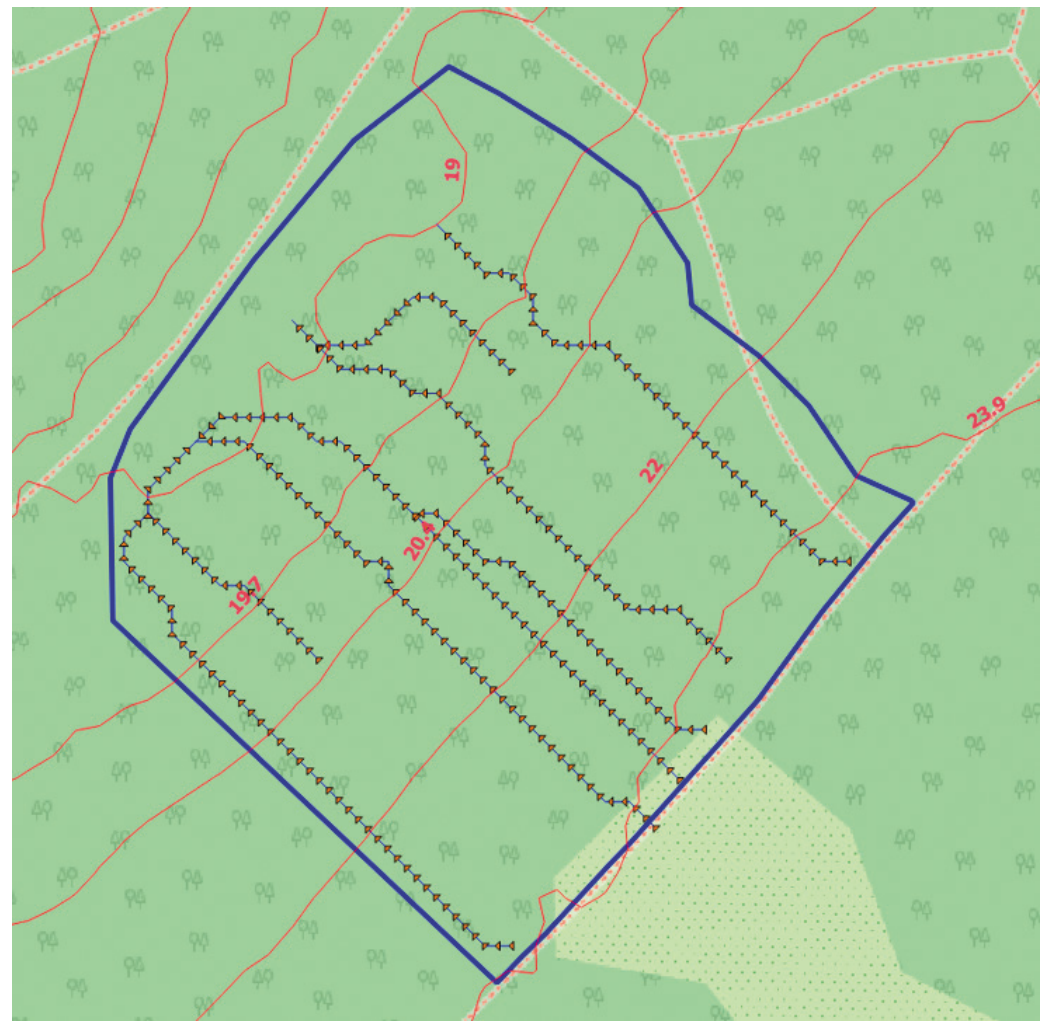

Fig. 8 Rainwater runoff routing at the Birch Lawn as generated by the DTM, QGIS. 
soil infiltration rate of $5 \mathrm{~mm} / \mathrm{h}$ (worst case equivalent to clay soil) below the depth of the raingarden, the raingarden was determined to require an overall surface area of $130 \mathrm{~m}^{2}$, a central depth of $450 \mathrm{~mm}$ and an overall volume of almost $60 \mathrm{~m}^{3}$. The size of the raingarden is related to the large catchment area adjacent to the Birch Lawn that contributes rainwater runoff.

\section{Amended soil}

To ensure the raingarden has the ability to intercept, hold and absorb rainfall, the soil within it was amended to provide enhanced infiltration and absorption capabilities. The existing soil was mixed with compost made on site, and sand and gravel to specified particle range sizes and proportions. Figs 9 and 10 show samples of the selected sand and gravel, respectively. The composition of the soil was specifically

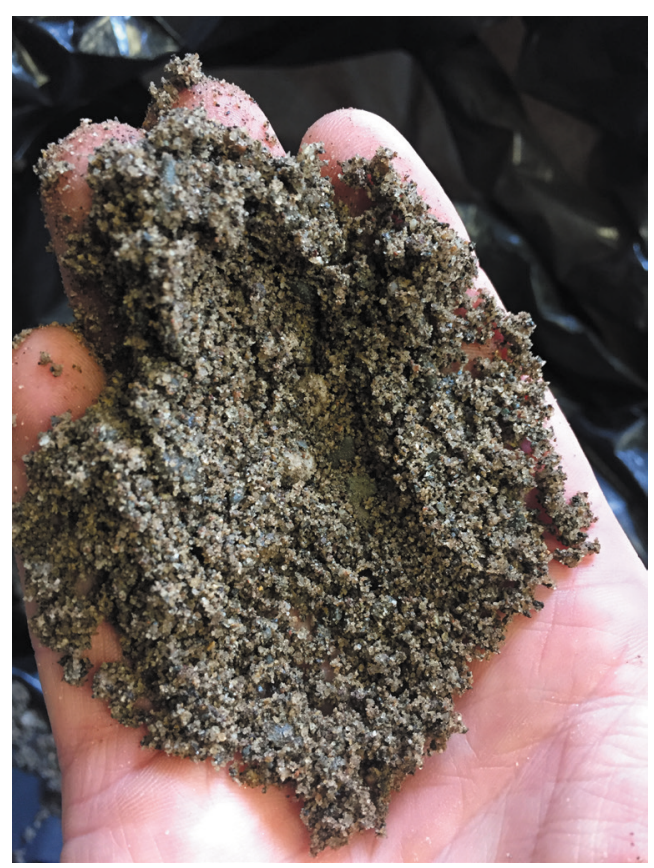

Fig. 9 A sample of the sand used in the amended raingarden soil. The sand had a particle range size of 0.06 to $2 \mathrm{~mm}$. Photo: David Kelly, Heriot-Watt University. developed to ensure enhanced infiltration, as well as providing sufficient organic material and nutrients to support the plants.

The SuDS Manual (Woods-Ballard et al., 2015) sets out design recommendations for the filter medium of bioretention systems such as raingardens. High design soil infiltration rates of between 100 and 300 $\mathrm{mm} / \mathrm{h}$ are recommended to accommodate rainfall flowing from contributing areas and to account for a drop in infiltration rate during the lifetime of the raingarden due to clogging and compaction, a process which can be delayed by root growth and the movement of soil invertebrates (Mehring \& Levin, 2015). Whilst there are few studies that look at the long-term performance of raingardens (Flynn \& Traver, 2013), The SuDs Manual suggests remedial action to the filter media may be needed after around

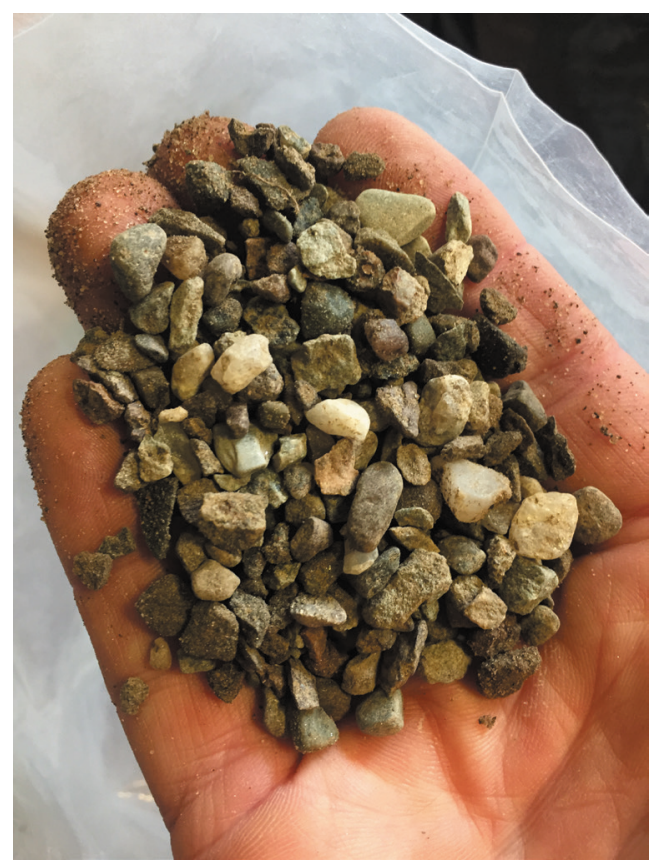

Fig. 10 A sample of the gravel used in the amended raingarden soil. The gravel had a particle range size of 2 to $6 \mathrm{~mm}$. Photo: David Kelly, Heriot-Watt University. 
20 years. For this study, two compositions of amended soil are being trialled in the raingarden to assess the long-term impact of soil composition on plant health: (i) 30 per cent existing soil, 45 per cent sand, 10 per cent gravel and 15 per cent compost - as suggested in The SuDS Manual (WoodsBallard et al., 2015); and (ii) 45 per cent existing soil, 35 per cent sand, 8 per cent gravel and 12 per cent compost.

\section{Plant selection and maintenance}

The plants used in a raingarden are an important part of its functionality, largely affecting its efficiency in terms of rainwater absorption. The plants aid rainwater runoff management by improving soil infiltration and retention capacity in the root zone, and enhancing evaporation and transpiration via the vegetation. On the other hand, low monoculture vegetation, such as simple mown turf or grass areas, has been found to be less effective at providing rainwater runoff management since it is poor at soaking up or trapping excess rainfall.

\section{Selected planting}

Various native and non-native plants were selected, with each species being compared and monitored over time to assess how well it coped with occasional drought and flood conditions within the raingarden. Plants characterised as having relatively high rates of evapotranspiration were specifically selected, as were plants that would help encourage and attract wildlife diversity, such as those that would provide nectar sources for insects and bees, food for seed-eating birds and habitats for invertebrates.

The planting has included both Scottish native and non-native plants. There are strong ethical and ecological reasons why native plants are the first choice, but the use of non-natives can be just as effective in this environment. RBGE has a remit to enhance biodiversity and it displays plants from around the world, with this global perspective being an important part of its mission. For people at home, the main focus when planting their own gardens should be to use plants of known biodiversity benefit from sustainable sources.

The selected native plants include Saxifraga granulata, Succisa pratensis, Anthyllis vulneraria, Filipendula ulmaria, Cicerbita alpina, Knautia arvensis and Festuca altissima. The non-native plants include Aruncus gombalanus (China), Ligularia fischeri (E Asia), Aquilegia formosa (Western $\mathrm{N}$ America), Primula poissonii (China) and Hosta sieboldiana (Japan). All were grown onsite from seed at the RBGE Nursery. Figs 11-13 show a selection of the young nursery plants.

Plants were generally selected that were known to thrive in wet conditions; however, levels of moisture can vary in a raingarden from very wet in the centre, where ponding is allowed to occur, to very dry at the edge. Part of the experimental aspect of the raingarden is to investigate which plants thrive in the very wet conditions and which survive drought periods too. Plants such as Filipendula ulmaria, Cicerbita alpina (native), Ligularia fischeri and Aruncus gombalanus have been planted at the centre of the raingarden and towards the far side which receives overland flow. Others, such as Aquilegia formosa and Anthyllis vulneriana, were planted at the near side edge of the raingarden where drier conditions are expected.

This planting complements a number of established native and non-native trees that were already growing at the Birch Lawn, 
including Alnus glutinosa (native), Betula pendula (native), Corylus avelana (native), Quercus robur 'Filicifolia' (cultivar of a native species), Alnus japonica (Japan), Alnus rubra (North America), Betula alleghaniensis (NE North America), Betula papyrifera (N North America), Betula nigra (USA), Corylus sieboldiana (Japan, Korea) and Populus alba (S and Central Europe). In addition, a non-native herbaceous plant, Gunnera manicata (Brazil), is already established at the Birch Lawn.

Planting of the raingarden took place in March 2019. Fig. 14 shows this in progress with members of the horticulture team having laid out the young plants ready for planting. Once complete, a layer of gravel was spread over the bioretention area of the raingarden and organic mulch was added to the surrounding area. These gravel and mulch layers were used to help retain soil moisture during dry periods, whilst also helping to protect the amended soil from erosion, aid plant establishment and reduce maintenance by suppressing weeds.

The plants developed well in the months following planting. Fig. 15 shows the raingarden in the summer of 2019 , with the planting having become well established.

Fig. 16 was taken that same summer and shows the different layers of planting, ranging from those at the edge of the raingarden where soil conditions are drier, to those at the centre and far side where wetter conditions are expected. Figs 17 and 18 show the raingarden in spring 2020 after the mulch surrounding the raingarden had been renewed.

\section{The raingarden biodiversity}

Over the year following its completion, the raingarden has provided enhanced biodiversity value having been shown to

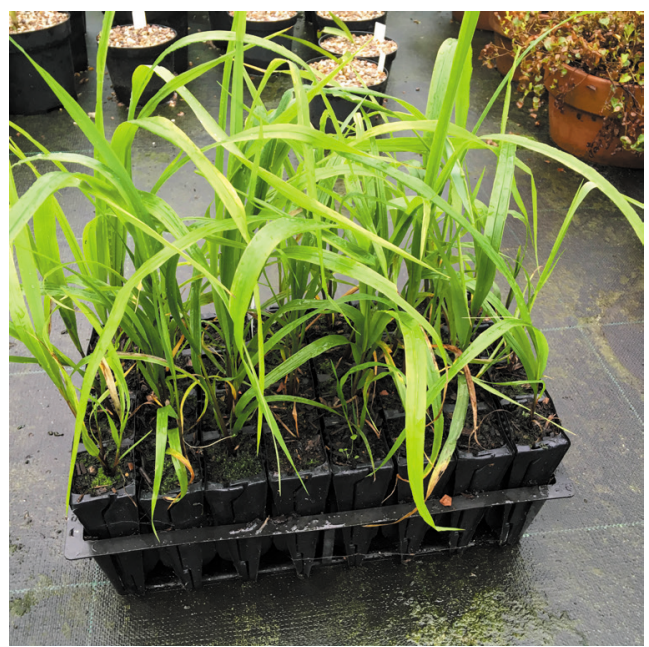

Fig. 11 Festuca altissima grown from seed at the RBGE Nursery (August 2018). Photo: Natacha Frachon, RBGE.

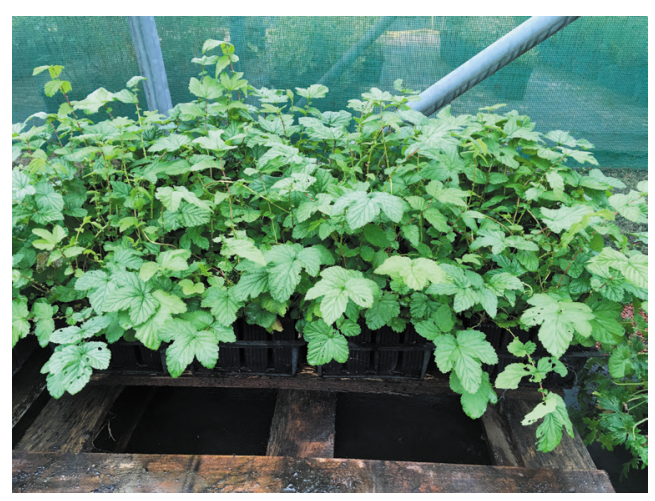

Fig. 12 Filipendula ulmaria grown from seed at the RBGE Nursery (August 2018). Photo: Natacha Frachon, RBGE.

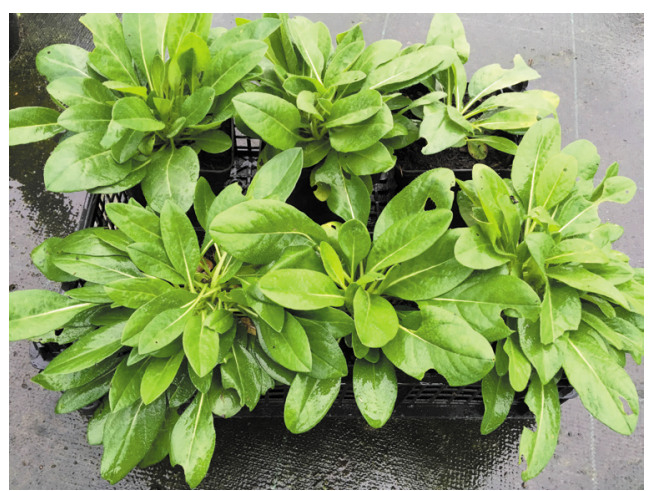

Fig. 13 Succisa pratensis grown from seed at the RBGE Nursery (August 2018). Photo: Natacha Frachon, RBGE. 


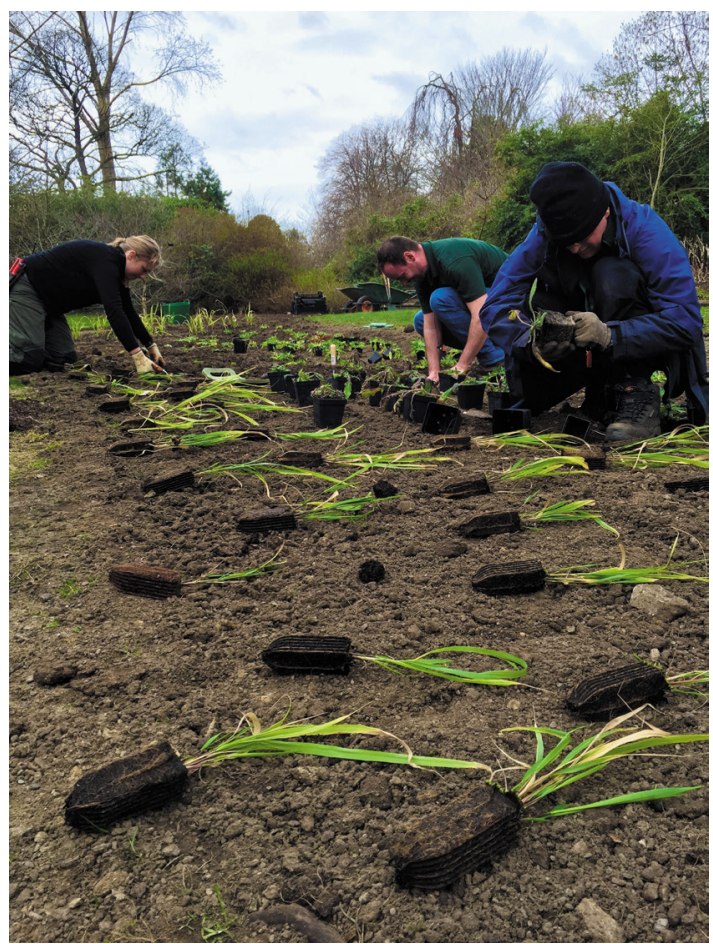

Fig. 14 Members of the horticulture team lay out the young plants before planting into the amended soil of the raingarden. Photo: David Kelly, Heriot-Watt University.

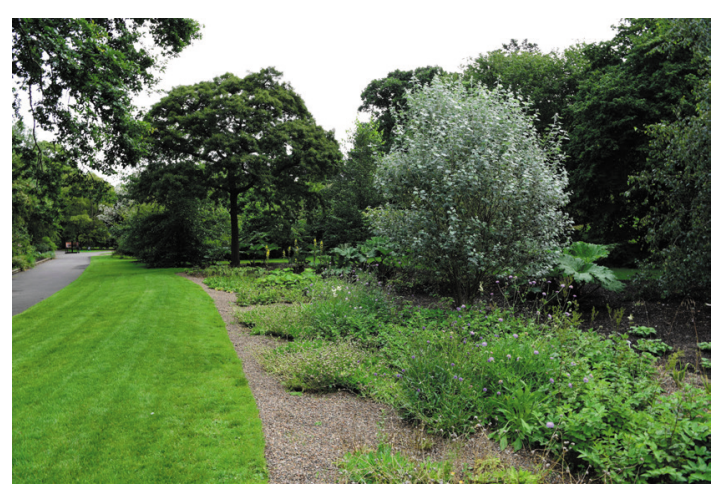

Fig. 15 A view of the raingarden from its west side in summer 2019, showing the planting now well established. Photo: Kirsty Wilson, RBGE.

attract insects and bees that enjoy the nectar from its blossoming flowers, and other wildlife given shelter from its growing canopy. Fig. 19 shows an example of the wildlife attracted by the raingarden.

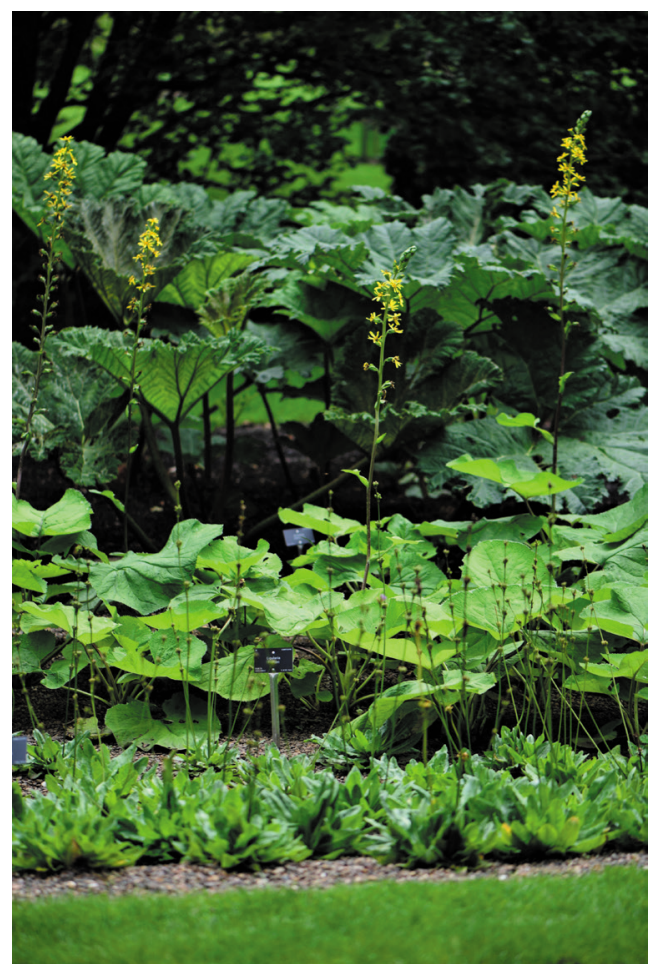

Fig. 16 A close-up view of the raingarden in summer 2019, showing the different layers of planting. Photo: Kirsty Wilson, RBGE.

\section{Raingarden maintenance}

The raingarden at RBGE was designed to be low maintenance. There is no open bare soil. The ground is dominated by the planting, and gravel is used as a mulch to help infiltration and reduce weeds. Although weeding was required in the first few months, once a good vegetation cover was established, the need for weeding was reduced. The herbaceous perennials in the planting will require to be cut back in winter and early spring, and only in exceptionally dry conditions will the area be irrigated.

\section{Raingarden performance during storm events}

To assess how well the raingarden performed during its first year, rainfall data recorded at RBGE was used to identify storm events 


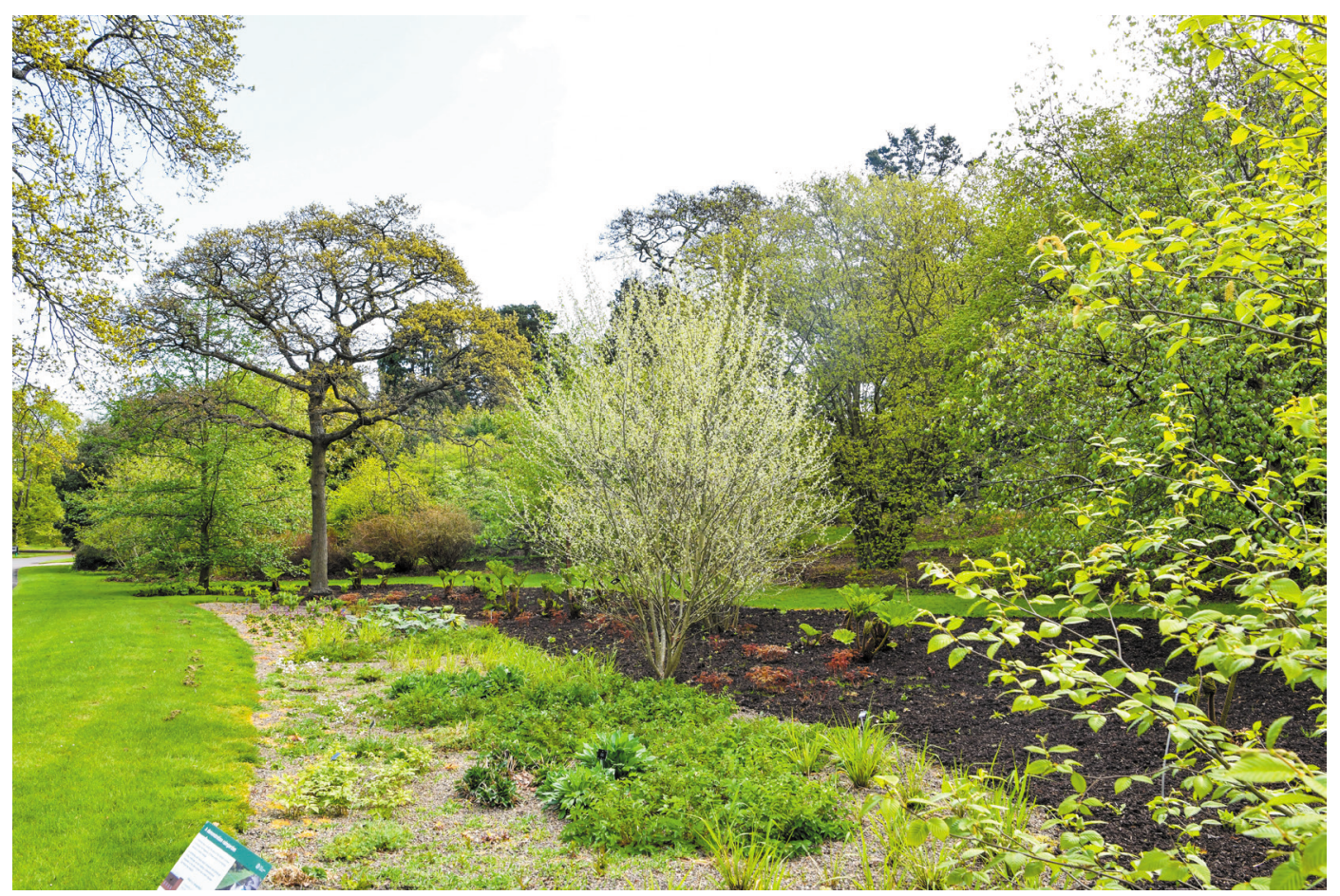

Fig. 17 The raingarden in spring 2020 following the addition of new mulch to the surrounding area. Photo: Kirsty Wilson, RBGE.

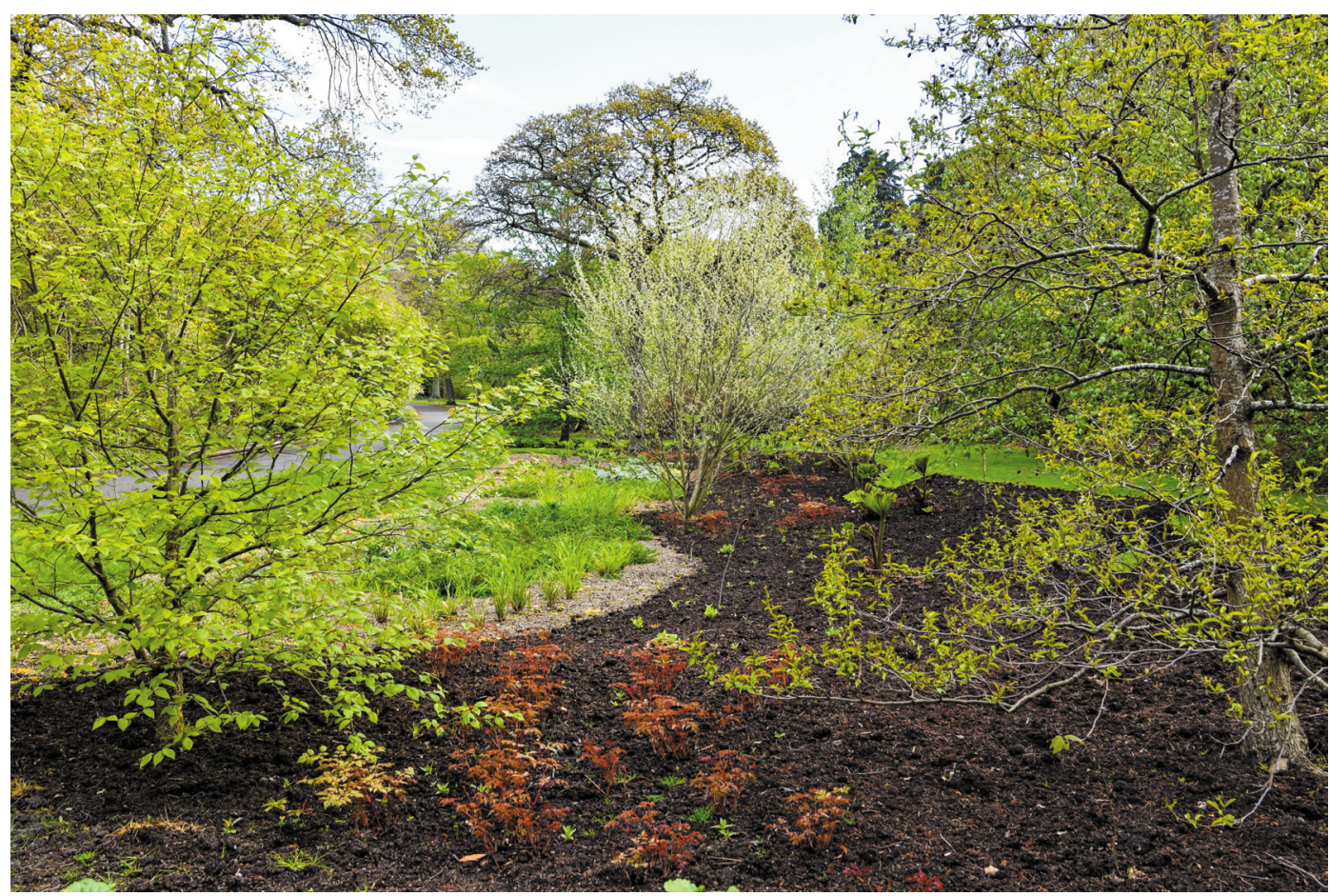

Fig. 18 New mulch added to the area surrounding the raingarden, taken in spring 2020. Photo: Kirsty Wilson, RBGE. 


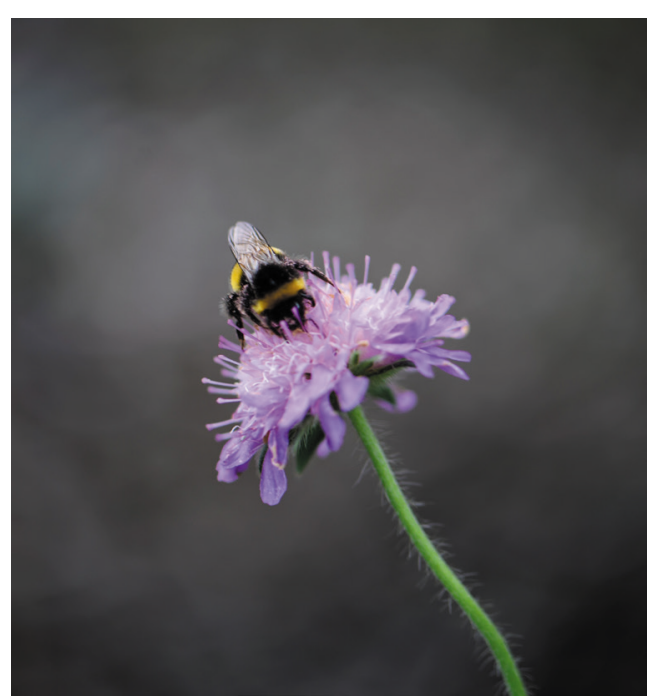

Fig. 19 A bumblebee nectars on a flower of Knautia arvensis (Scottish native). Photo: Kirsty Wilson, RBGE.

experienced by the raingarden between spring 2019 and spring 2020. Both the Met Office and the Scottish Environmental Protection Agency (SEPA) maintain tipping bucket rain gauges at RBGE. The available rainfall data from the Met Office rain gauge was processed to a relatively coarse one-hour timestep, whilst that from the SEPA rain gauge was available at a higher resolution based on time-of-tip $(0.2 \mathrm{~mm})$. Therefore, the data from the SEPA rain gauge was used. A number of significant storms were found to have occurred during that period, and all seasons were wetter than average (compared with the long-term average rainfall from 1976 to 2019).

The spring of 2019 (March to May) recorded $161 \mathrm{~mm}$ of rain (1.16 times more than the average). In summer 2019 (June to August) $314 \mathrm{~mm}$ of rain was recorded (1.62 times more than the average). An intense storm event was observed on the evening of 10 August 2019 with a rainfall intensity greater than $50 \mathrm{~mm} / \mathrm{h}$ for around ten minutes. Based on the $\mathrm{FEH} 13$ rainfall
Depth-Duration-Frequency (DDF) model, the storm had an estimated return period of 1 in 18 years. Between 6 and 11 August 2019 a total of $107 \mathrm{~mm}$ of rain was recorded, which is equivalent to a storm return period of 1 in 27 years.

The autumn of 2019 (September to November) saw $258 \mathrm{~mm}$ of rain (1.3 times more than the average). More frequent and longer spells of rain were observed during winter 2019/2020 (December to February) with $274 \mathrm{~mm}$ of rain (1.51 times more than the average). Observed rainfall in February 2020 was $147 \mathrm{~mm}$ (3.06 times more than the average for February - $48 \mathrm{~mm}$ ) which is primarily attributed to two major storm events (Storm Ciara and Storm Dennis), both of which unfolded in quick succession that month, making it the wettest February recorded at RBGE since 1976.

Despite the number of intense storms, and the higher than average rainfall, no flooding occurred at the Birch Lawn. In fact, the raingarden successfully intercepted and attenuated excess storm runoff and helped to avoid waterlogging of plant beds whilst maintaining access to visitors.

\section{Discussion and conclusion}

In recent years, the Birch Lawn at RBGE has suffered from waterlogging and localised flooding following heavy rainfall events. The results from the DTM show that the Birch Lawn sits at one of the lowest elevation points within the Garden and so watershed from surrounding slopes culminates at this point. In addition, infiltration tests of the soil within the Birch Lawn indicate very low rates of soil infiltration overall. The creation of an experimental raingarden at the Birch Lawn, with enhanced infiltration capacity, has aimed to capture and retain the rainfall, allowing it to infiltrate naturally into the 
ground. Since its completion in spring 2019, the raingarden has successfully attenuated excess rainfall runoff during heavy storms, helping to avoid floods on nearby paths and minimising waterlogging of surrounding lawns and plant beds. In providing a simple, attractive and wildlife-friendly way of reducing flood risk, it is hoped that the raingarden will also raise awareness around nature-based solutions for flood mitigation and provide inspiration for visitors and other institutions who may need to solve similar problems.

The raingarden will function as a 'living laboratory' to enable RBGE staff and visitors to learn more about raingarden hydrology and associated plant health, particularly with regard to native plants and their ability to cope with occasional drought and flood conditions. It will also act as a valuable demonstration tool for public engagement on sustainable flood management techniques.

At $\mathrm{RBGE}$, the raingarden will also be helpful with regard to understanding and planning future site management strategies for coping with an unpredictable and changing climate, to ensure uninterrupted provision of the important public amenity. The impact of extreme wet and dry weather presents many challenges to the Garden, particularly in terms of plant health, garden maintenance and visitor experience. As climate change is expected to bring even greater weather variability throughout the year, and more frequent and intense extreme events, resilience planning is therefore crucial to minimise future risk.

\section{References}

BRAY, B., GEDGE, D., GRANT, G. \& LEUTHVILAY, L. (2012). Rain Garden Guide. RESET Development, London.

\section{CENTRE FOR ECOLOGY AND HYDROLOGY}

(2013). Flood Estimation Handbook, Centre for Ecology and Hydrology, Wallingford.

FLYNN, K.M. \& TRAVER, R.G. (2013). Green infrastructure life cycle assessment: a bio-infiltration case study. Ecological Engineering, 55: 9-22.

FOULKES, J. (2017). The value of community engagement in botanic gardens with examples from the Royal Botanic Garden Edinburgh.

Sibbaldia: The Journal of Botanic Garden Horticulture, 15: 121-128.

KELLY, D.A., KNOTT, D., WILSON, K. \&

KALAICHELVAN, A. (2019). The hydrology and biodiversity characteristics of an experimental raingarden at RBGE in Scotland. CIB W062, 45th International Symposium on Water Supply \& Drainage for Buildings, Melbourne, Australia, 7-10 September 2019.

MARTIN, S. (2014). Climate ready? Exploring the impact and lessons from recent extreme events at Royal Botanic Garden Edinburgh for climate change adaptation in the horticulture sector. Sibbaldia: The Journal of Botanic Garden Horticulture, 12: 155-170.

MEHRING, A.S. \& LEVIN, L.A. (2015). Potential roles of soil fauna in improving the efficiency of rain gardens used as natural stormwater treatment systems. Journal of Applied Ecology, 52(6): 1445-1454.

MURPHY, J.M., HARRIS, G.R., SEXTON, D.M.H., KENDON, E.J., BETT, P.E., CLARK, R.T., EAGLE, K.E., FOSSER, G., FUNG, F., LOWE, J.A., MCDONALD, R.E., MCINNES, R.N., MCSWEENEY, C.F., MITCHELL, J.F.B., ROSTRON, J.W., THORNTON, H.E., TUCKER, S. \& YAMAZAKI, K. (2018). UKCP18 LAND Projections: Science Report. Met Office Hadley Centre, Exeter.

NATURAL RESOURCES CONSERVATION SERVICE (1986). Urban hydrology for small watersheds. Technical Release 55. United States Department of Agriculture, Natural Resources Conservation Service.

NOVÁK, V. (2012). Evapotranspiration in the Soil-Plant-Atmosphere System: Progress in Soil Science. Springer, Dordrecht.

RBGE (2019). Our history. Available online: https:// www.rbge.org.uk/about-us/our-history/ (accessed May 2020). 
16 David A. Kelly, Kirsty Wilson, Aravindan Kalaichelvam \& David Knott

WOODS-BALLARD, B., WILLSON, S., UDALECLARKE, H., ILLMAN, S., SCOTT, T., ASHLEY, R. \& KELLAGHER, R. (2015). The SuDS Manual (C753). CIRIA, London.
ZHANG, S. \& GUO, Y. (2013). Explicit equation for estimating storm-water capture efficiency of rain gardens. Journal of Hydrologic Engineering, 18(12): 1739-1748. 